\title{
MANAJEMEN KEPEMIMPINAN KIAI DALAM MENINGKATKAN KECERDASAN EMOSIONAL SANTRI PONDOK PESANTREN HUSNUL RI'AYAH SUBOH SITUBONDO
}

\author{
Riayatul Husnan \\ Institut Agama Islam Negeri Jember \\ husnansitubondo@gmail.com
}

\begin{abstract}
Abstrak
Kepemimpinan kiai dalam pondok pesantren sangat penting karena pesantren merupakan lembaga pendidikan yang misi utamanya untuk mencetak generasi penerus bangsa yang berakhlak mulai. Pesantren menjadi tempat yang aman dan nyaman dalam pembelajaran serta mampu menarik minat para remaja untuk belajar di dalamnya. Untuk itu, fungsi manajemen pesantren sangat penting diterapkan. Penelitian ini difokuskan pada bagaimana manajemen kepemimpinan kiai dalam meningkatkan kecerdasan emosional santri di Pondok Pesantren Husnul Ri'ayah Suboh Situbondo. Penelitian ini menggunakan pendekatan kualitatif deskriptif. Peneliti membahas secara gamblang permasalahan yang terjadi. Berdasarkan fokus penelitian dan metode yang digunakan, penelitian ini sampai pada simpulan bahwa manajemen kepemimpinan kiai di Pondok Pesantren Husnul Ri'ayah secara fungsi manajemen planing,organizing, actuating, controling sudah terlaksana dengan baik. Peningkatan kecerdasan emosional santri di Pondok Pesantren Husnul Ri'ayah dipengaruhi oleh pengelolaan manajemen yang baik. Oleh karena itu profesionalitas kepemimpinan seorang kiai dalam menjalankan roda oranisasi pesantren khususnya dalam penggerakan mempunyai peran yang sangat penting. Seorang kiai dituntut mampu menumbuhkan semangat belajar dan selalu memotivasi para santri dalam setiap kegiatan, bukan hanya menjalankan kewajiban semata tetapi lebih pada itu kecerdasan emosionalnyapun benar-benar tercapai berasaskan sosial keagamaan.
\end{abstract}

Kata Kunci: kepemimpinan kiai, kecerdasan emosional, santri 


\begin{abstract}
The leadership of kyai in an Islamic boarding school is important, as an Islamic boarding school is an institution having the main goal to generate promising generation who has akhlaqul karimah. Islamic boarding school needs to be such a safe and comfortable place in implementing the learning process and attracting students' interest to learn, and for that reason the management aspect of Islamic boarding school needs to be well established. This study is focused on How Kiai Management develops POAC to Improve Santri's Emotional Intelligence in Islamic Boarding School of Husnul Ri'ayah Suboh Situbondo. This study uses a descriptive qualitative approach where researchers discuss clearly the problems that occur. Based on the focus of the research and the methods used, this study concluded that the Management of Kiai Leadership in Husnul Ri'ayah Islamic Boarding School, in the managerial functions of Planning, Organizing, Actuating, Controling has been implemented very well. The increase in students' emotional intelligence in the Husnul Ri'ayah Boarding School is influenced by good managemen. Therefore the professionalism of a kiai's leadership in running the boarding school organization especially in mobilizing the santro has a very important role. How a kiai is able to foster a spirit of learning and always motivate students in every activity, not only carry out their obligations but also his emotional intelligence has been achieved well based on religious social.
\end{abstract}

Keywords: leadership of kiai, emotional intelligence, santri

\title{
Pendahuluan
}

Ilmu pengetahuan dan teknologi telah berkembang pesat di era globalisasi saat ini. Perkembangan ini membawa dampak positif dan negatif yang bisa dirasakan oleh negeri. Banyaknya budaya asing yang jauh dari tradisi Indonesia menjamur dan menguasai generasi. Hal ini menyebabkan krisis akhlak yang terjadi hampir di semua lapisan masyarakat, mulai dari pelajar hingga pejabat. Di kalangan pelajar misalnya, dapat dilihat dari meningkatnya angka kriminalitas yang dilakukan oleh calon pewaris masa depan bangsa, mulai dari kasus narkoba, pembunuhan, pelecehan seksual, tawuran, korupsi dan lain sebagainya. Pemerintah dengan berbagai macam upaya telah mencoba memperbaikinya dari segala bidang. Salah satu bidang yang dikembangkan dan ditingkatkan adalah pendidikan. 
Pendidikan sebenarnya juga mengalami krisis. Krisis yang dihadapi pada umumnya adalah krisis adab, bukan krisis tarbiyyah atau ta'lim, sebab kenyataannya pendidikan dan pengajaran telah berlangsung di mana-mana. Oleh karena itu, selain tarbiyah dan ta'lim juga diperlukan ta'dib (peng-adab-an). ${ }^{1}$ Karena itu, sampai saat ini pendidikan masih diyakini mempunyai peran besar dalam membentuk karakter dan mampu menjadi guiding light bagi generasi muda penerus bangsa. Pentingnya pendidikan juga telah diterangkan dalam Al-Quran Surat An-Nahl ayat 78:

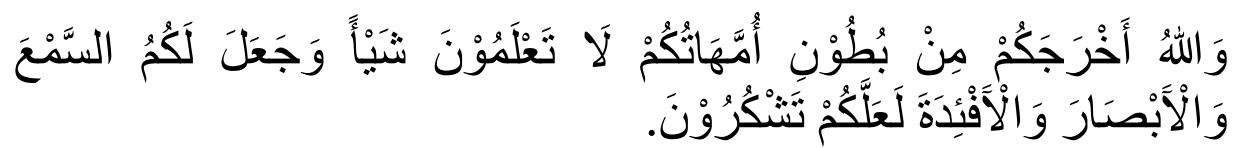

"Dan Allah mengeluarkan kamu dari perut ibumu dalam Keadaan tidak mengetahui sesuatupun, dan Dia memberi kamu pendengaran, penglihatan dan hati, agar kamu bersyukur."

Pendidikan pesantren diyakini mampu memfilter perkembangan budaya luar dengan baik, sehingga tetap bisa survive di tengah-tengah derasnya arus globalisasi yang dapat berpengaruh terhadap eksistensinya. Pesantren dianggap sebagai model institusi pendidikan yang mempunyai keunggulan, baik dalam tradisi keilmuannya yang dinilai sebagai tradisi yang agung (great tradition), maupun pada sisi transmisi dan internalisasi moralitasnya yang dapat dipertanggung jawabkan. ${ }^{3}$ Dengan alasan inilah, pesantren tetap diharapkan mampu mengubah moralitas generasi bangsa yang humanis dan beradap. Harapannya, para alumni pesantren dapat menjadi khalifah fil ardhi yang memiliki tiga aspek, yaitu: kebenaran, kebaikan, dan seni. Maksudnya, mereka memiliki ilmu pengetahuan, akhlaq yang terpuji, dan mencintai seni. 4

${ }^{1}$ Moh. Achyat Ahmad, dkk, Mengapa Saya Harus Mondok di Pesantren (Pasuruan: Pustaka Sidogiri, 2009), 109.

${ }^{2}$ Departeman Agama,. Al-Quran dan Terjemahnya. (Bandung: PT Sygma Examedia Arkanleema, 2009), 16:78.

${ }^{3}$ Malik Fajar, Holistika PemikiranPendidikan (Jakarta: Raja Grafindo Persada, 2005), 76.

${ }^{4}$ Ridlwan Nasir, Mencari Tipologi Format Pendidikan Ideal: Pondok Pesantren Di Tengah Arus Perubahan, (Yogyakarta: Pustaka Pelajar, 2005), 340. 
Dalam pesantren ada seorang top figure yang dipanggil dengan sebutan kiai. Dia memiliki peran signifikan dalam menggerakkan semua aktivitas pesantren, sehingga kiai menjadi pusat perhatian dan suri teladan di segala aspek kehidupan para santri. Hal ini selaras yang diungkapkan oleh Ulwan dalam Rachman dan Hijran bahwa keteladanan merupakan metode influentif untuk membentuk dan mempersiapkan moral, spritual dan kecakapan sosial peserta didik yang keberhasilannya paling meyakinkan dalam pendidikan. 5 Peran Kiai dalam pesantren merupakan figure sentral panutan, otoritatif, dan pusat seluruh kebijakan serta perubahan, hal ini menunjukkan pentingnya manajemen kepemimpinan kiai dalam lembaga pondok pesantren guna meningkatkan kecerdasan emosial santri, sehingga mampu membentuk santri-sanrti yang religius, intelektual dan humanis di era globalisasi yang menjadi tantangan ditengah-tengah masyarakat.

\section{Pembahasan}

\section{Manajemen Kiai}

Manajemen pada dasarnya merupakan suatu proses penggunaan sumber daya secara efektif untuk mencapai sasaran atau tujuan tertentu. Terry dalam bukunya Principle of Management mengemukakan: "Management is district process of planning, organizing, actuating, controlling, performed to determine and accomplish stated objective the use of human beings and other resources." Dari pengertian ini, manajemen merupakan proses mengelola sumberdaya organisasi untuk mencapai tujuan yang telah ditetapkan secara efektif dan efisien.

Manajemen secara etimologis memiliki arti kata yang sepadan dengan kata mengelola, memeriksa, mengawasi dan mengurus. Oleh sebab itu, ketika kata "manajemen" disandingkan dengan kata lain akan memiliki implikasi dan ruang lingkup yang berbeda atau bahkan lebih spesifik. Contohnya, kata manajemen disandingkan dengan kata pesantren, maka akan membahas tentang ruang lingkup manajemen dari kiai atau mengurus

${ }^{5}$ M.F. \& Hijran, Rachman, Kajian Keteladanan dalam Memperkuat Pendidikan Indonesia, The 5th Urecol Proceeding, 18 February, (Yogyakarta: UAD, 2017), 998 - 1003.

${ }^{6}$ George Tery, Prinsip-PrinsipManajemen. (Jakarta: BumiAksara, 1991), 2 
pesantren mengenai pengelolaan dan pengembangannya. ${ }^{7}$ Banyak sumber daya manajemen yang terlibat dalam lembaga pendidikan, termasuk di dalamnya lembaga pendidikan pesantren, antara lain manusia, sarana dan prasarana, biaya, teknologi, dan informasi. Namun demikian, sumber daya yang terpenting adalah sumber daya manusia. Bagaimana seorang manager (kiai) di pesantren mampu menyediakan tenaga, bakat kreativitas, dan semangatnya. Karena tugas terpenting yang harus dilakukan seorang kiai dalam pendidikan pesantren adalah menyeleksi, menempatkan, melatih, dan mengembangkan sumber daya manusia. ${ }^{8}$ Dengan demikian, manajemen merupakan kemampuan dan keterampilan khusus yang dimiliki oleh seorang kiai untuk melakukan suatu kegiatan baik dikelola sendiri maupun dengan bantuan orang lain dalam upaya mencapai tujuan pesantren untuk mencapai pendidikan yang produktif, efektif, dan efisien.

Pesantren merupakan bagian dari pendidikan nasional yang telah ada sebelum kemerdakaan dan bahkan disinyalir sebagai lembaga pendidikan yang memiliki kekhasan, keaslian (indegeneous) Indonesia. Kiai dipandang secara ideal oleh komunitas pesantren sebagai sentral figur yang memiliki kelebihankelebihan yang tidak dimiliki oleh orang lain pada umumnya. Peran kiai dalam pandangan ideal tersebut sangat vital baik sebagai mediator, dinamisator, motivator maupun sebagai motor penggerak komunitas yang dipimpinnya. Keberadaan kiai bukan sekedar menjadi wakil untuk menjalin hubungan dengan dunia di luar pesantren, melainkan juga dalam rangka melindungi kepentingan masyarakat serta lembaga-lembaga Islam. ${ }^{9}$

Sudah menjadi common sense bahwa pesantren lekat dengan figur kiai. Kiai dalam pesantren adalah tokoh sentral, otoritatif, dan pusat seluruh kebijakan serta perubahan. Mubarok dalam Jalil, menyatakan bahwa 83 persen anak dipengaruhi oleh apa yang dilihatnya, 11 persen dipengaruhi oleh apa yang didengarnya,

${ }^{7}$ Sukarji dan Umiarso, Manajemen dalam pendidikan Islam, Konstruksi Teoritis dan Filosofis dalam Menemukan Kebermaknaan Pengelolaan Pendidikan Islam (Jakarta: Mitra Wacana Media, 2014), 15.

${ }^{8}$ Ibid.,13.

${ }^{9}$ Horikosi dalam Irwan Abdullah et. al., Agama, Pendidikan Islam dan Tanggung jawab Sosial Pesantren (Yogyakarta, Sekolah Pasca Sarjana UGM, 2008), 128. 
dan 6 persen dipengaruhi oleh rangsangan/stimulus. Praktik lapangannya adalah kiai dalam pondok pesantren memberikan contoh seperti terjun ke lapangan bekerja secara langsung bukan hanya sekedar berbicara saja dalam majelis. ${ }^{10}$ Hal ini erat kaitannya dengan dua faktor berikut. Pertama, kepemimpinan yang tersentralisasi individu yang bersandar pada kharisma serta hubungan yang bersifat kekeluargaan. Kedua kepemilikan pesantren bersifat individual (atau keluarga). ${ }^{11}$ Kiai adalah cendekiawan agama (ulama), kiai tidak memperoleh gelar dari sistem pendidikan formal, tetapi gelar yang disandang dari masyarakat. Istilah kiai dalam Bahasa Jawa dipakai dalam banyak hal. Semua hal ini digunakan untuk menunjukkan sesuatu atau seseorang yang memiliki kualitas di atas rata-rata. ${ }^{12}$

Dalam pendidikan, pesantren harus mampu mengembangkan dua potensi yaitu potensi pendidikan dan potensi kemasyarakatan, sehingga nantinya bisa melahirkan generasi bangsa yang tidak saja mahir dalam ilmu pengetahuan keagamaannya, luas wawasan pengetahuan, dan cakrawala pemikirannya, tetapi juga akan mampu memenuhi tuntutan zamannya dalam rangka pemecahan persoalan kemasyarakatan. ${ }^{13}$

Kebanyakan dari pondok pesantren menerapkan pola manajemen yang berorientasi pada penanaman jiwa ketulusan, keihlasan dan kesukarelaan yang biasa dikenal dengan istilah khusus "lillahi ta'ala" (semata-mata karena Allah SWT). Konsep lillahi ta'ala tersebut menjiwai hampir semua aktivitas pada pondok pesantren, sehingga konsep tersebut dapat menjadi modal dasar utama keihlasan dalam kehidupan. ${ }^{14}$

Kiai sebagai pimpinan di pondok pesantren dibantu oleh para ustadz dan santri senior untuk memberikan pelajaran kepada santri-santrinya, misalnya pembelajaran kitab salaf yang berisi tentang kajian fiqih, tauhid, dan akhlak. Meskipun demikian, kekuasaan tertinggi tetap berada di tangan kiai. Betapapun

10 J.Jalil, Pendidikan Karakter Implementasi oleh Guru, Kurikulum dan Sumber Daya Pendidikan. (Jakarta: CV Jejak, 2018), 32

${ }^{11}$ Sulthon dan Moh. Khusnuridlo, Manajemen Pondok Pesantren dalam Perspektif Global, 30.

${ }^{12}$ Ronald Alan Lukens - Bull, Jihad Ala Pesantren di Mata Antropolog Amerika (Yogyakarta: Gama Media, 2004), 88.

${ }^{13}$ Sahal Mahfudz, Pesantren Mencari Makna, 3.

${ }^{14}$ Ibid.,33. 
demokratisnya kepemimpinan kiai, tetap saja masih ada jarak tidak terjembatani antara kiai dan keluarganya di satu pihak, dan para guru serta santri di pihak lain. Kiai dalam konteks ini bertindak sebagai pemilik tunggal (single owner). ${ }^{15}$ Kiai dianggap memiliki sesuatu yang tidak dimiliki oleh orang lain di sekitarnya. Dengan status demikian, dia befungsi sebagai pengasuh dan pembimbing santri dalam banyak hal. Fungsi ini memunculkan peranan kiai sebagai peneliti (researcher), filter dan assimilator terhadap aspekaspek kebudayaan luar yang masuk ke dalam pondok pesantren. Dengan demikian, kiai sebagai culture broker menjadi nyata. Aspekaspek kebudayaan yang telah diseleksi oleh kiai akan dikembangkan para santri di lingkungan masyarakat sendiri. ${ }^{16}$

\section{Fungsi manajemen Kiai dalam pesantren}

1. Perencanaan (Planing)

Merencanakan pada dasarnya menentukan kegiatan yang hendak dilakukan di masa depan. Kegiatan ini dimaksud untuk mengatur berbagai sumber daya agar hasil yang dicapai sesuai dengan yang diharapkan, ${ }^{17}$ yaitu proses memikirkan dan menetapkan kegiatan-kegiatan atau program-program yang akan dilakukan pada masa yang akan datang untuk mencapai tujuan tertentu dalam hal stabilitas kegiatan pembelajaran di pesantren. Perencanaan merupakan salah satu dari fungsi manajemen yang menjadi prioritas dalam manajemen pesantren, karena dalam perencanaan inilah perkembangan pesantren dapat ditingkatkan. Maka untuk itu, perlu direncanakan program yang akan dilaksanakan secara berkesinambungan yakni program jangka pendek, jangka menengah dan jangka panjang. ${ }^{18}$

Kata kunci yang paling penting dalam perencanaan adalah efektif dan efisien yang biasanya diterjemahkan dalam penyusunan rencana dengan rumusan $5 \mathrm{~W}+1 \mathrm{H}$, yaitu what (apa) yang akan dilakukan, why (mengapa) harus melakukan

${ }^{15}$ Abdurrahman Wahid dalam Muhtarom, Reproduksi Ulama di Era Globalisasi (Yogyakarta: Pustaka Pelajar, 2005), 110.

${ }^{16}$ Muhtarom, Reproduksi Ulama di Era Globalisasi (Yogyakarta: Pustaka Pelajar, 2005), 111.

${ }^{17}$ Nanang Fattah, Landasan Manajemen Pendidikan, 49.

${ }^{18}$ As'ari, TranSparansi Manajemen Pesantren Menuju Profesionalisme (Jember: STAIN Jember Press, 2013), 93. 
apa, when (kapan) melakukan apa, where (dimana) melakukan apa, who (siapa) yang melakukan apa, dan how (bagaimana) cara melakukan apa.

2. Pengorganisasian (Organizing)

Istilah organisasi mempunyai dua pengertian umum. Pertama organisasi diartikan sebagai suatu lembaga atau kelompok fungsional, misalnya sebuah perusahaan, sebuah sekolah, sebuah perkumpulan, dan badan-badan pemerintahan. Kedua, merujuk pada proses pengorganisasian yaitu bagaimana pekerjaan diatur dan dialokasikan diantara para anggota sehingga tujuan organisasi itu bisa dapat tercapai secara efektif. ${ }^{19}$ Pengorganisasian sebagai proses membagi kerja ke dalam tugastugas yang lebih kecil, membebankan tugas-tugas itu kepada orang yang sesuai kemampuannya, dan mengalokasikan sumber daya, serta mengkoordinasikannya dalam rangka efektivitas pencapaian tujuan organisasi. Oleh sebab itu, pengorganisasian merupakan bentuk kegiatan yang pola utamanya adalah "kesesuaian" antara subyek yang akan melakukan dengan media yang digunakan. ${ }^{20}$

Pengorganisasian dalam pesantren sangat dibutuhkan keefektifannya, untuk memudahkan kiai memanajemen pesantren sehingga tujuan pendidikan akan lebih mudah tercapai. Dalam pengorganisasian ada dua aspek utama yang perlu diperhatikan terutama dalam proses susunan struktur organisasi yaitu:

Pertama, departementalisasi, yaitu pengelompokan kegiatan-kegiatan kerja organisasi agar kegiatan-kegiatan sejenis saling berhubungan serta dapat dikerjakan bersama. Dengan pengelompokan ini juga, subyek yang akan melakukan kegiatan mudah untuk menyelesaikan kegiatan tersebut secara terorganisir, teratur, dan terencana. Konsep ini akan tercermin pada struktur formal suatu organisasi dan tampak atau ditunjukkan oleh bagan suatu organisasi pendidikan dengan alur kegiatan yang jelas.

Kedua, pembagian kerja (job description), yaitu perincian tugas pekerjaan agar setiap individu bertanggung jawab dalam melaksanakan sekumpulan kegiatan. Dengan pembagian kerja,

${ }^{19}$ Ibid. 71.

${ }^{20}$ Sukarji dan Umiarso, Manajemen dalam pendidikan Islam, 37. 
organisasi pendidikan memiliki ciri khusus yang lebih spesifik pada peningkatan mutu pendidikan melalui pelayanan yang diberikan di lembaga pendidikan.

3. Pelaksanaan (actuating)

Pelaksanaan yang juga biasa disebut dengan penggerakan atau pengarahan adalah menggerakkan dan mengarahkan orangorang untuk mencapai tujuan yang telah ditetapkan secara efektif dan efisian. Siagian dalam Suhadi berpendapat bahwa pelaksanaan adalah seluruh proses memberikan motivasi untuk bekerja kepada bawahan sehingga mereka mau bekerja secara ikhlas dalam rangka mencapai tujuan organisasi. ${ }^{21}$

Dalam hal ini keprofesionalan kiai dalam memanajemen pesantren khususnya dalam penggerakan mempunyai peran yang sangat penting. Bagaimana seorang kiai mampu menumbuhkan semangat belajar dan selalu memotivasi para santri dalam setiap kegiatan untuk berasaskan sosial bukan hanya menjalankan kewajiban semata.

Dalam sebuah pesantren, penjadwalan kegiatan harian bagi santri sangat diperlukan. Hal ini akan membentuk kepribadian santri untuk lebih disiplin dan bertanggung jawab.

4. Pengawasan (controlling)

Pengawasan (controlling) adalah proses mengukur pelaksanaan dan tujuan-tujuan, menentukan sebab-sebab penyimpangan-penyimpangan dan mengambil tindakantindakan korektif yang dianggap perlu. Pengawasan dapat dimaknai sebagai usaha untuk mengetahui sejauh mana perencanaan yang dibuat itu tercapai secara efektif dan efisien, hingga akhirnya diadakan evaluasi sebagai alat untuk mengetahui keberhasilannya. Selanjutnya dibuat langkahlangkah alternative untuk permasalahan-permasalahan atau tujuan yang belum tercapai secara maksimal (feed back), dan diadakan tindak lanjut (follow up) bagi tujuan yang telah tercapai. ${ }^{22}$

Beberapa kalangan menilai bahwa diantara beberapa fungsi manajemen, fungsi perencanaan dan pengawasan mempunyai peran yang sangat penting dalam sebuah organisasi

\footnotetext{
${ }^{21}$ Siagiandalam Suhadi, Manajemen Berbasis Sekolah (Jember: Pena Salsabila,
} 2011), 54 .

${ }^{22}$ Sukarji dan Umiarso, Manajemen dalam pendidikan Islam, 42. 
atau lembaga. Fungsi perencanaan menetapkan tentang apa yang harus dicapai pada periode tertentu, sedangkan dalam pengawasan berusaha mengevaluasi apakah tujuan yang telah ditetapkan dapat dicapai dengan baik, kalau belum maka dicari faktor penyebabnya, sehingga dapat dilakukan tindakan perbaikan (corrective action). ${ }^{23}$

\section{Kecerdasan Emosional}

Kecerdasan dalam arti umum merupakan suatu kemampuan yang dimiliki seseorang dalam memahami dan menyadari terhadap apa yang dialaminya baik melalui pikiran, perkataan, dan perbuatan. ${ }^{24}$ Menurut Peter dan John, kecerdasan emosional adalah "Emotional Intelligence is ability to perceive emotions to acces and generate emotions so as to assist thought. ${ }^{25}$ Kecerdasan emosional adalah kemampuan lebih yang dimiliki seseorang dalam memotivasi diri, ketahanan dalam menghadapi kegagalan, mengendalikan emosi dan menunda kepuasan, serta mengatur keadaan jiwa. ${ }^{26}$

1. Bentuk-bentuk Kecerdasan Emosional

a. Kesadaran Diri

Kesadaran diri berarti memiliki pengertian yang mendalam akan emosi diri, juga kekuatan dan keterbatasan diri, serta nilai-nilai dan motif diri. Orang-orang yang memiliki kesadaran diri yang kuat adalah orang-orang yang realistis, yaitu yang tidak suka mengkritik dan jujur tentang diri mereka sendiri. ${ }^{27}$ Pada wilayah ini diperlukan adanya pemantauan perasaan dari waktu ke waktu agar timbul wawasan dan pemahaman tentang diri. Ketidakmampuan untuk mencermati perasaan yang sesungguhnya membuat diri

\section{${ }^{23}$ Ibid, 43.}

${ }^{24}$ Al.Tridhonanto, Melejitkan Kecerdasan Emosi (EQ) Buah Hati(Jakarta: PT Elex Media Komputindo, 2010),4.

${ }^{25}$ Peter Salovey dan John Mayor dalam Yacinta Senduk, Mengasah Kecerdasan Orang Tua untuk Mendidik Anak: Latihan-latihan Praktis yang Memberikan Wawasan Baru untuk Orang Tua 8.

${ }^{26}$ Ibid, 6.

${ }^{27}$ Daniel Goleman, Primal Leahership: Kepemimpinan Berdasarkan Kecerdasan Emosi, Terj. Susi Purwoko (Jakarta: PT Gramedia Pustaka Utama, 2007), 45. 
berada dalam kekuasaan perasaan. Sehingga tidak peka akan perasaan yang sesungguhnya yang berakibat buruk bagi pengambilan keputusan. ${ }^{28}$

Kesadaran diri mutlak diperlukan ketika seseorang ingin mengubah hidup. Fokus pada tindakan dan reaksi yang sering kali membantu mengembangkan kemampuan diri dalam menjelaskan apa, kenapa, dan apa yang terjadi pada tubuh seseorang ketika melakukan sesuatu.

b. Mampu Mengelola Emosi

Kemampuan dalam mengelola emosi sebagai landasan dalam mengenali diri sendiri atas emosi. ${ }^{29}$ Misalnya, ketidakmampuan anak untuk mengekspresikan emosinya berpengaruh pada kesehatan fisik dan mental. Emosi memegang peranan penting dalam penyesuaian diri karena akan mempengaruhi anak-anak pada saat mereka tumbuh menjadi dewasa.

c. Motivasi

Motivasi ibarat bahan bakar yang menggerakkan mesin. Tanpa harapan, tidak seorang pun akan pernah bisa termotivasi. Motivasi adalah membuat orang melakukan sesuatu karena mereka ingin melakukannya. Hal ini juga berlaku bagi kita semua, jika benar-benar ingin melakukan sesuatu, kita akan membutuhkan motivasi. Bagaimana cara menyalurkan emosi terhadap orang lain? Sebenarnya kita harus mengerti prinsip tentang rasa sakit dan kenikmatan..$^{30}$

d. Mampu menjalin sosial dengan orang lain.

Perilaku sosial terhadap lingkungan adalah bagaimana cara seseorang bersikap dan berperilsku baik dengan lingkungan yang dimiliki. Berdasarkan penelitian, seseorang yang memiliki hubungan dekat (sosial network), ikatan batin erat dengan orang lain, seperti suami, istri, tema, sahabat, tetangga, maka ia akan lebih sehat secara psikis dan mampu

${ }^{28}$ Al. Tridhonanto, Beranda Agency, Meraih Sukses dengn Kecerdasan Emosional (Jakarta: PT Elex Media Komputindo, 2010) 25.

${ }^{29}$ Ibid, 25

${ }^{30}$ Richard Denny, Motivate to Win: Cara Memotivasi Diri (Jakarta: Gramedia Pustaka Utama, 2007), 14. 
mengatasi, menetralisasi akibat-akibat negative dari stress kerja. ${ }^{31}$

\section{Peran Kiai dalam Mengembangkan POAC}

Kiai memiliki peran sangat penting dalam perkembangan kecerdasan emosional santri, karena kiai merupakan contoh panutan yang paling berpengaruh pada santri-santrinya. Temuan ini mendukung temuan penelitian yang menyatakan bahwa keteladanan lebih efektif digunakan dalam pembelajaran. keprofesionalan kiai dalam memanajemen pesantren akan berdampak pada setiap individu santri. Sebagaimana yang telah dilakukan oleh K.H Ahmad Ghazi Syaif manajemen pesantren dalam hal perencanaan, pengorganisasian, pelaksanaan, dan pengawasan dalam setiap hal telah diprioritaskan agar visi misi pesantren dapat tercapai.

K.H Ahmad Ghazi Syaif termasuk orang-orang yang memiliki keahlian manajemen yang baik. Peran kiai sebagai mediator, dinamisator, supervisor, dan motivator yang menjadi penggerak bagi para santri mampu dijalankannya dengan baik. Beliau berusaha semaksimal mungkin untuk memanajemen pesantren menjadi pesantren yang nyaman dan aman sebagai tempat pembelajaran, fungsi manajemen yang beliau terapkan antara lain:

a. Perencanaan (Planning)

Dalam hal perencanaan, K.H Ahmad Ghazi Syaif sangat menginginkan para santri menjadi pribadi yang berilmu sekaligus beramal. Setiap ilmu yang diketahui harus diikuti dengan amal atau praktek langsung, hingga pembelajaran menjadi lengkap dan lebih mudah difahami. K.H Ahmad Ghazi Syaif dengan dibantu oleh para asatid wal asatidah membuat perencanaan untuk meningkatkan kualitas santri. Dalam beberapa bulan ke depan, akan menambah koleksi kitab di perpustakaan, meskipun saat ini buku-buku umum dan kitabkitab klasik sudah tersedia. Para santri juga bisa menambah refrensi melalui internet.K.H Ahmad Ghazi Syaif berharap wawasan para santri tidak hanya seputar kitab dan buku-buku ilmiah saja, tapi juga tentang berita-berita uptodate yang terjadi di luar pesantren, di Indonesia bahkan di dunia.

${ }^{31}$ Triantoro Safaria dan Kunjana Rahardi, Menjadi Pribadi Berprestasi (Jakarta: PT. Raja Grafindo), 59. 
Pelatihan menulis juga merupakan salah satu program yang direncanakan oleh K.H Ahmad Ghazi Syaif beliau berharap santri mampu berekspresi melalu sebuah tulisan, menuangkan ide-ide atau gagasan dan opini berdasarkan ilmu pengetahuan, fakta atau fiktif saja.

b. Pengorganisasian (Organizing)

K.H Ahmad Ghazi Syaif berharap para santri mengerti bagaimana makna organisasi sesungguhnya. Bukan hanya mengerti secara struktural saja, tapi juga mengerti makna sesungguhnya. Organisasi adalah bagaimana dua orang atau lebih bisa bekerja sama untuk mencapai sebuah tujuan yang sama. Setiap kegiatan yang dilakukan di pesantren pasti sudah ada yang mengelola. Misalnya, dalam kegiatan akhir al-sanah sebelum bulan Ramadhan, ada koordinator pelaksana, sekretaris, bendahara, seksi humas dan lain sebagainya. Pengorganisasian ini tentunya menambah pengetahuan dan pengalaman baru bagi para santri.

Tujuan dari pengorganisasian kegiatan ini, K.H Ahmad Ghazi Syaif berharap santri mampu belajar menjadi pemimpin dalam masyarakat. Para santri diberikan kewajiban, hak, dan kepercayaan dalam mengelola, mengatur, dan mengurusi acara yang akan dilaksanakan. Setiap santri diberi kebebasan untuk mengkonsep acara sesuai dengan kesepakatan bersama.

c. Pelaksanaan (Actuating)

Pondok Pesantren Husnul Ri'ayah senantiasa mempraktikkan setiap kegiatan khususnya yang berhubungan dengan ilmu kajian fiqih. Misalnya, pada bulan Ramadhan, para santri mengkaji kitab fiqh zakat, yang berisi tentang seluk beluk zakat, penerima zakat, dan berapa jumlah zakat, baik zakat Mal atau zakat fitrah.

Setelah kajian selesai, kira-kira pada tanggal 25 Ramadhan, K.H Ahmad Ghazi Syaif dibantu oleh para ustadz dan santri menjadi amil zakat. Beliau menyalurkan zakat pada ratusan fakir miskin. Pemilihan mustahiq zakat sangat ditekankan kepada orang-orang yang benar-benar tidak mampu, seperti kepada fakir miskin, janda, tua renta, dan sebagainya.

Pelaksanaan ini memberikan pengetahuan sekaligus pengalaman kepada para santri menjadi amil zakat. Sehingga semua santri merasa termotivasi untuk melakukan hal yang 
sama, dan nantinya santri akan mampu mempraktekkan dalam kehidupan bermasyarakat.

d. Pengawasan (Controlling)

Dalam hal pengawasan K.H Ahmad Ghazi Syaif memfungsikan para pengurus pondok pesantren yaitu asatidz wa asatidzah untuk senantiasa mengontrol setiap kegiatan yang di laksakan, bahkan terkadang juga memfungsikan peran warga sekitar pondok pesantren dengan sistem penjagaan yang ketat adalah salah satu hal penting yang juga menjadi bentuk pengawasan terhadap keberadaan santri. Semua warga sekitar pon-pes menjadi pengawas terhadap kegiatan santri di luar pesantren. Hal ini, menjadi tantangan bagi para santri. Mereka harus mampu mengembangkan emosional dalam ranah sosial sehingga bisa menjalin hubungan baik dengan warga sekitar pesantren. Selama kegiatan yang dilakukan positif maka akan mendapat support dan motivasi dari para warga sekitar.

\section{Manajemen Kepemimpinan Kiai dalam Meningkatkan Kecerdasan Emosional Santri}

Pondok Pesantren Husnul Ri'ayah merupakan pesantren yang menjadikan kecerdasan emosional santri sebagai tujuan kesuksesan. Sebagaimana pernyataan K.H Ahmad Ghazi Syaif bahwasanya ketika santri sudah berada di masyarakat, dia tidak ditanyakan buku atau kitab apa saja yang telah dipelajarinya selama sekolah, tapi bagaimana cara dia menghadapi problematika sosial berdasarkan ilmu pengetahuan yang telah didapatkan. Pondok Pesantren Husnul Ri'ayah mengartikan kecerdasan emosional santri sebagai kemampuan yang dimiliki seseorang dalam memahami dan menyadari terhadap apa yang dialaminya, baik melalui pikiran, perkataan, dan perbuatan. Kecerdasan emosional yang dimaksud ini dalam ranah sosial, bagaimana santri mampu bersikap menghargai terhadap orang lain. Kecerdasan ini tidak bisa didapatkan dari membaca ilmu pengetahuan saja, tapi akan diperoleh jika dipraktekkan. Pesantren adalah tempat yang paling tepat untuk mempelajari dan mendapatkan kecerdasan emosional. Kenapa demikin? Karena di pesantren berkumpul berbagai macam karakter individu yang berbeda.

Ada beberapa faktor penunjang kecerdasan emosional santri yang ada di Pondok Pesantren Husnul Ri'ayah ini.

a. Kegiatan shalat berjamaah bersama 
Kegiatan ini akan semakin menambah rasa kebersamaan dan kerukunan dari para santri, mereka akan lebih dekat dan mudah dalam bergaul satu sama lain, hingga nantinya kata "teman saya" akan berganti menjadi "saudara saya".

b. Kegiatan Batsul Masa'il

Ada batsul masaill yang dilaksanakan untuk masyarakat umum, ada juga yang dilaksanakan setiap hari sabtu yang hanya diikuti santri dan ustadz saja. Diskusi ini mungkin hanya tentang masalah-masalah kecil, seperti hukumnya membaca Al-Quran dalam keadaan haid. Dalam diskusi ini, santri bisa menyampaikan pendapat yang mereka miliki, namun tentunya berdasarkan referensi kitab tertentu. Santri lainnya akan mendengarkan dan menghargai jawaban dari temannya. Dalam kegiatan ini, santri belajar bagaiaman cara memahami, mengerti, dan menghargai pendapat orang lain.

c. Pelatihan Menulis

Menulis adalah cara mengekspresikan dan mengaplikasikan pemikiran melalui sebuah tulisan. Tulisan bisa berhubungan dengan ilmu pengetahuan, fakta seputar lingkungan, sejarah, atau opini mengenai suatu permasalahan. K.H Ahmad Ghazi Syaif selaku pengasuh senantiasa menganjurkan para santri untuk belajar menulis. Menulis bisa melatih kemampuan berkomunikasi santri melalui sebuah teks atau bacaan. Hal ini menunjukkan, salah satu target dan harapannya adalah agar santri tidak hanya mampu berdakwah melalui fisik dan perkataan saja, tapi juga melalui sebuah karya.

\section{Simpulan}

Pesantren diyakini mampu membentuk karakter kepribadian seseorang. Dalam pesantren diajarkan bagaimana cara menghargai diri sendiri dan orang lain, menghadapi berbagai macam karakter dengan kepribadian berbeda, berbicara santun dan sopan, menghargai pendapat dan bertanggung jawab. Pesantren saat ini sudah banyak diminati oleh masyarakat. Pesantren diyakini menjadi tempat terbaik untuk membentuk kepribadian anak tentang kecerdasan emosional dalam ranah sosial. Seperti halnya Pondok Pesantren Husnul Ri'ayah, dalam pesantren ini terdapat berbagai macam karakter dari para santri, dari santri satu dan santri lainnya jelas berbeda, hal ini bisa disebabkan karena santri datang 
dari berbagai macam wilayah di Jawa Timur, ada yang berbahasa Jawa, dan Madura, ada yang bersifat pemarah, egois, kalem, lemah lembut, cengeng dan lain sebagainya. Dalam satu kamar santri bisa mengenal banyak karakter, hal ini menjadi pembelajaran dan contoh untuk kehidupan bermasyarakat di masa depan. K.H. Ahmad Ghazy Syaif mampu menerapkan memanajemen pesantren dengan sangat baik. Terbukti dengan berbagai kegiatan yang dilaksanakan mampu menunjang kecerdasan emosional santri. Beliau mengatur dan mengelola sumber daya sesuai dengan porsinya, berbagai macam bentuk perencanaan, pengorganisasian, pelaksanaan, dan pengawasan berjalan dengan sangat baik. Perencanaan, pengorganisasian, pelaksanaan, dan pengawasan yang dilakukan di Pondok Pesantren Husnul Ri'ayah, semuanya menunjang terhadap pembentukan dan peningkatan kecerdasan emosional santri. Sebagaimana harapan beliau untuk menjadikan santri yang disiplin, bertanggung jawab, dan menghargai diri sendiri serta orang lain.

\section{Referensi}

Ahmad, Moh. Achyat, dkk. Mengapa Saya Harus Mondok di Pesantren?. Pasuruan: Pustaka Sidogiri.

As'ari. 2013. TranSparansi Manajemen Pesantren Menuju Profesionalisme. Jember: STAIN Jember Press.

Daniel Goleman. 2007. Primal Leahership: Kepemimpinan Berdasarkan Kecerdasan Emosi, Terj. Susi Purwoko. Jakarta: PT Gramedia Pustaka Utama.

Denny, Richard. 2007. Motivate to Win: Cara Memotivasi Diri. Jakarta: Gramedia Pustaka Utama.

Departemen Agama RI. 2009. Al-Quran dan Terjemahnya. Bandung: PT Sygma Examedia Arkanleema.

Fajar, Malik. 2005. Holistika PemikiranPendidikan. Jakarta: Raja Grafindo Persada.

Fattah, Nanang. 2009. Landasan Manajemen Pendidikan . Bandung: PT Remaja Rosdakarya.

Jalil, J. 2018. Pendidikan Karakter Implementasi oleh Guru, Kurikulum dan Sumber Daya Pendidikan. Jakarta: CV Jejak. 
Lukens, Ronald Alan - Bull. 2004. Jihad Ala Pesantren di Mata Antropolog Amerika. Yogyakarta: Gama Media.

Masruroh, Ninik dan Umiarso. 2011. Modernisasi Pendidikan Islam Ala Azyumardi Arza. Jogjakarta: Ar-Ruzz Media.

Muhtarom. 2005. Reproduksi Ulama di Era Globalisasi. Yogyakarta: Pustaka Pelajar.

Nasir, Ridlwan. 2005. Mencari Tipologi Format Pendidikan Ideal: Pondok Pesantren Di Tengah Arus Perubahan. Yogyakarta: Pustaka Pelajar.

Rachman, F. \& Hijran, M. 2017. Kajian Keteladanan dalam Memperkuat Pendidikan Indonesia, The 5th Urecol Proceeding, 18 February, Yogyakarta: UDY

Safaria, Triantoro dan Kunjana Rahardi. 2008. Menjadi Pribadi Berprestasi. Jakarta: PT. Raja Grafindo.

Senduk, Yacinta. 2007. Mengasah Kecerdasan Orang Tua untuk Mendidik Anak: Latihan-latihan Praktis yang Memberikan Wawasan Baru untuk Orang Tua. Jakarta: PT Elex Media Komputindo.

Sukarji dan Umiarso. 2014. Manajemen dalam pendidikan Islam, Konstruksi Teoritis dan Filosofis dalam Menemukan Kebermaknaan Pengelolaan Pendidikan Islam. Jakarta: Mitra Wacana Media.

Sulthon dan Moh. Khusnuridlo. 2006. Manajemen Pondok Pesantren dalam Perspektif Global. Yogyakarta: Laksbang Pressindo.

Tridhonanto, Al dan Beranda Agency. 2010. Meraih Sukses dengn Kecerdasan Emosional. Jakarta: PT Elex Media Komputindo.

Tridhonanto, Al. 2009. Melejitkan Kecerdasan Emosi (EQ) Buah Hati. Jakarta: PT Elix Media Komputindo.

Wahid, Abdurrahman,. 2005. Pesantren sebagai Sub Kultural", dalam Muhtarom, Reproduksi Ulama di Era Globalisasi. Yogyakarta: Pustaka Pelajar.

Winoto, Suhadi. 2011. Manajemen Berbasis Sekolah. Jember: Pena Salsabila. 